\title{
The Sound Picture of the Saami
}

\section{Shamanic Drum}

\author{
By Rolf KRISTOFfersSoN
}

Research on the Saamı shamanic drum has mainly concerned the pictorial world of the drumheads The missionaries of the 17th and 18 th centuries who produced the first written sources for our knowl edge of Saamı culture and religion described carefully what they saw and heard, but were unable to understand the shamanic element of Saamı belief Their frame of reference for understanding non Chrıstran religion was the world of the Bible and Graeco Roman antıquity (e g. Forbus 1910)

In the religio cultural conflict the drum became a symbol of resistance against the Christian mission Within their own conceptual framework, the missionaries described the drum as an instrument of witchcraft (Rheen 1897, $33 \mathrm{f}$ ) In this connection the pictures on the drumskins acquired the utmost interest as a source for the Saamı world view and concept of the divine world Another principle interest was their function in divination

In his study Lappalarsten uskonto (Holmberg 1915) Uno Holmberg states that the Saamı shaman, the noande, originally used the drum solely as an ald to attaining shamanic ecstasy The divinatory use, in his opinion, is a late development (Holmberg 1987, 91) Holmberg accepts Fritzner's supposition that the use of the Saamı drum in divination was influenced by European soothsaying with the help of sieves, a method used during the 16 th century (Fritzner 1877) There is a technical similarity between one type of Saamı drum and the sieves, but this explanation seems rather simplistıc I will here, among other things, suggest an alternative explanation based on the shamanic use of sound

Andrew Neher has published results of research on the effect of drum sounds on the electrical activity of the central nervous system (Neher 1961, Neher 1962) Human hearing covers a range of approximately: 16 to $20,000 \mathrm{HZ}$, a little more than ten octaves (Möller 1976, 26) The sense reaction to the sound volume, the amplitude, increases when the frequency rises, $1 \mathrm{e}$ when the pitch becomes higher (Möller 1976, 
27) The human auditory faculty accepts a higher sound pressure, or amplitude, for low frequencies before the pain threshold is reached than it does for higher frequencies

The frequency of a drum depends on its size, on the tension of the skin and the weight of the skin per $\mathrm{cm}^{2}$ the greater the size, the lower the frequency; the higher the tension, the higher the pitch; and the heavier the drumskin, the lower the pitch The pattern of harmonics in the membranes is complicated (Sundberg 1973, $138 \mathrm{f}$ ) The node lines can be detected by modern technical equipment, and for round membranes these lines are given by Wilhelm Stauder (Stauder 1949$68,13,729$ f)
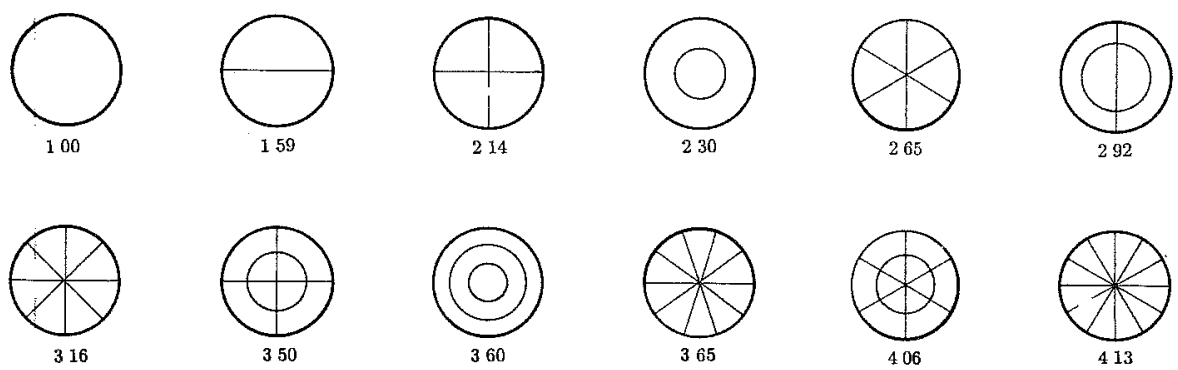

Fig 1 Node lines in a crrcular membrane The numbers refer to the relative frequency Stauder 1949-68, 13, 729

The Saami surviving drums are all different in size Most of them are slightly oval shaped (Manker 1938) The node lines, therefore, are supposedly even more complicated The frequencies according to size and other factors are low

What I have sard so far means that the drum sounds reach the receptive organs in the human ear in a range of low but strong tones, with low frequencies but high amplitude This means that more energy is transferred into the nervous system than with various other types of instrumental sounds

The frequency of the beat is another factor affecting the nervous system There are several types of brain waves appearing under special circumstances The so-called Theta waves, four to eight cycles per second, are related to trance conditions, dreaming and sudden insights A drum beating in this rythm is supposed to make it easy to attain trance conditions According to Michael Harner, Jilek and Ormestad 
have discovered "that drumbeat frequencies in the range of Theta waves in EEG were dominant during initiation processes when the Salish Indian drum of ioedeer hide was used (Harner 1983, $74 \mathrm{f}$, Jilek 1974,21 )

Fig 2 CEREBRAL WAVES

\begin{tabular}{|l|l|l|}
\hline $\mathrm{Hz}$ & Label & Characteristics \\
\hline $0,5-4$ & DELTA & A condition of deep sleep \\
\hline $4-8$ & THETA & $\begin{array}{l}\text { Drowsiness, dreaming Can rise in conditions } \\
\text { of intense alertness such as sudden insıght or } \\
\text { when a memory appears Trance conditions }\end{array}$ \\
\hline $8-14$ & ALFA & $\begin{array}{l}\text { Relaxed wakng state Habitual mental actıv- } \\
\text { ity Introverted attention Meditation }\end{array}$ \\
\hline $14-22$ & BETA & $\begin{array}{l}\text { Attention Concentrated mental activity but } \\
\text { also anxiety and restlessness }\end{array}$ \\
\hline $22-32$ & HIGH BETA & $\begin{array}{l}\text { Intensive reactions and thinking or intense anx- } \\
\text { lety }\end{array}$ \\
\hline $33-$ & $\begin{array}{l}\text { K-COMPLEX } \\
\text { and undefined }\end{array}$ & $\begin{array}{l}\text { Short outbreaks of high frequency waves dur- } \\
\text { ing problem solving and when short term mem- } \\
\text { ory becomes remforced }\end{array}$ \\
\hline
\end{tabular}

\section{Wonder \& Donovan 1984, 114}

The brain has a system of descending nerves connecting the cortex with the sensory apparatus The function of these nerves is not very clear, according to Aage Möller (Möller 1976, 27) It is known, how ever, that the brain processes the signal from the auditive receptors in the ear in three or four stages It is to be supposed that the descending connections direct the revision of the primary signal on its way to conscious recognition Rapid changes in frequency or amplitude 


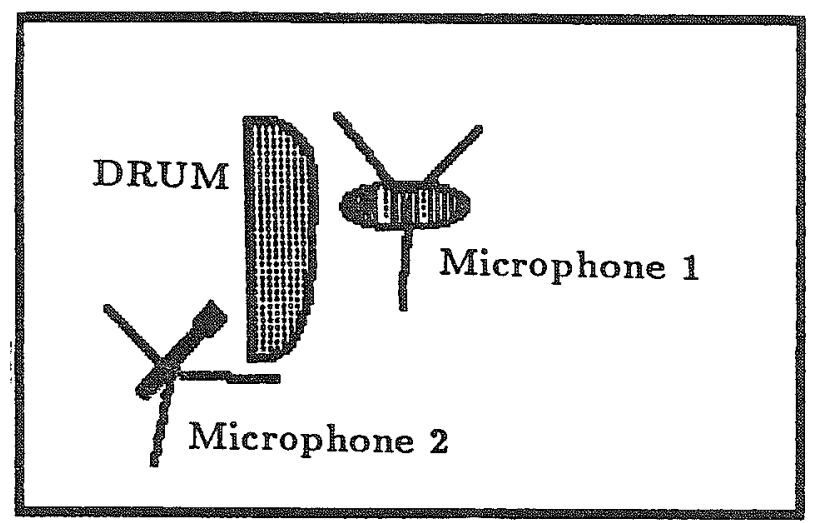

Fig 3 Arrangement of microphones for the recording of drum 67 The beats hit opposite mic 1 Tape recorder: Revox PR 99A; Tape: BASF ferro LH HiFi LP 35; Microphones: AKG C $451 \mathrm{E}$ and AKG D 130

seem to be accentuated Biologically, this means that changes in the surrounding sound pattern tend to strike conscious observation, while more stable sounds are suppressed A conscious or even an unconscious influence on auditory receptivity seems possible It is a well known fact that it is possible to become accustomed to certain sounds so that they are no longer noticed, e $g$ the ticking of a clock in the room

The drum sound is non-harmonic, shortlived and fluctuating in character It is unstable in amplitude and in percieved frequency The fre quency apprehended depends on the amplitude, which shifts rapidly In 1 ts general character the drum sound is close to rumbling

The special character of drum sounds might be a partial explanation of why drums are used in religious ceremonies all over the world It seems possible by study to increase the sensitivity for, and reaction to, certain types of sounds, and it is possible that such sensitivity training in sounds used in shamanic rites is a part of the initiation of shamans ${ }^{1}$

The sound of a drum also depends on the point at which the stick touches the drumskin "The membrane at this point is forced into an ocillation and all the harmonics which would have had a node at this point disappear" writes Johan Sundberg (Sundberg 1973, 31) So much for the theoretical problems of drum sounds In my study of the Saamı drum I have tried to find the answer to two questions: 1) Is it possible to detect the sound pictogram from some of the drums

1 There are only a few references in the literature to the trainng of new Saam shamans, e g Tornæus 1900; Olsen 1910 
preserved? 2) Are there marks of usage which might indicate what kind of sounds the users preferred?

Most of the surviving Saami drums are in such a condition that it is impossible to carry out any research on the original sound Through the courtesy of the Nordiska Museet in Stockholm, however, I have had the opportunty to record drum 67 (numbers according to Manker 1938) The recording was made on June 20,1988 , in a small auditorium in the Museum The drum was held in a vertical position with the microphones placed one on each side of the drumskin The beats were made by an onginal "hammer" (vetjier) (Fig 3)

As the original drums are very fragile, it is not possible to make more trying experiments with them In order to try more vigorous beating, I have produced a couple of experimental membranes myself These are made in the shape and size of an average Saamı drum, with a slightly oval shaped surface and ca $40 \mathrm{~cm}$ in length at the longest point One was technically speaking a shell drum made at first without holes in the bottom ${ }^{2}$ The sound of this drum was very weak and without character until I made openings in the wooden bottom When the openıngs were made, the sound became strong and rich This may indicate that the openings in the bottom of the shell drums are made as much for reasons of sound as because of the need of a handle I have made two frame drums, a wooden "hammer" and a "frog", arpa The "frog" is made by brass rings connected to a common ring in the centre $^{3}$

With reference to the arpa Samuele Rheen describes "a big bunch of brass rings bound to a brass chain" 4 The designation of the object as a frog (e.g Niurenius 1905,20$)$ is probably descriptive. The connected brass rings look, when placed on the drumskin, look quite alive if the skin is beaten with a hammer It vibrates and jumps in a manner remarkably similar to a frog Some small jumps, followed by a sudden higher one and so on. We will return to this question later

Regarding my second preliminary question about signs of use on the drumheads, I have carefully examined 21 drums at the Nordiska Museet In the reproductions made by Ernst Manker there are several

2 In the shell drum the drumskn is stretched over the opening of a wooden bowl The frame drum is built on a wooden frame made by a bent lath

3 In order to avold misunderstandings I must here make clear that my laboratory drums are in no way to be regarded as Saamı woodwork The matenal is plywood and board The drumskns are of goat hide and not decorated

4 Sw "een stoor kmppa Messingz Ringar tillsamman bundne widh ett Messingskiädh" Rheen 1897, 31 


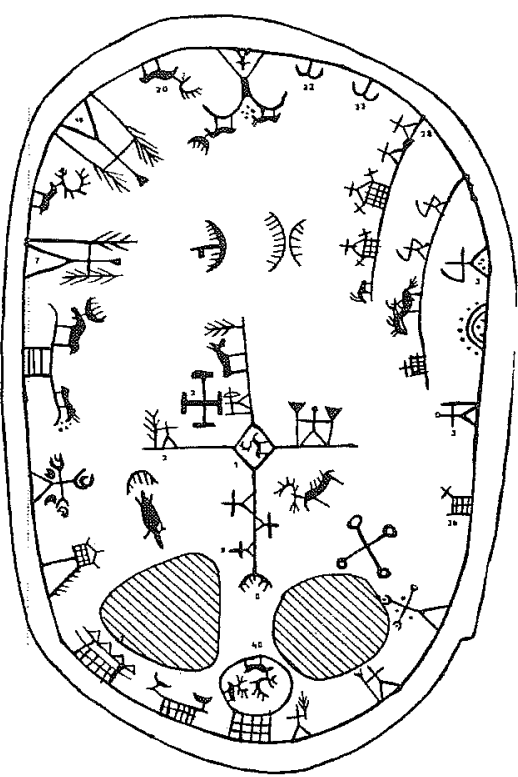

Fig 4 Drum 1

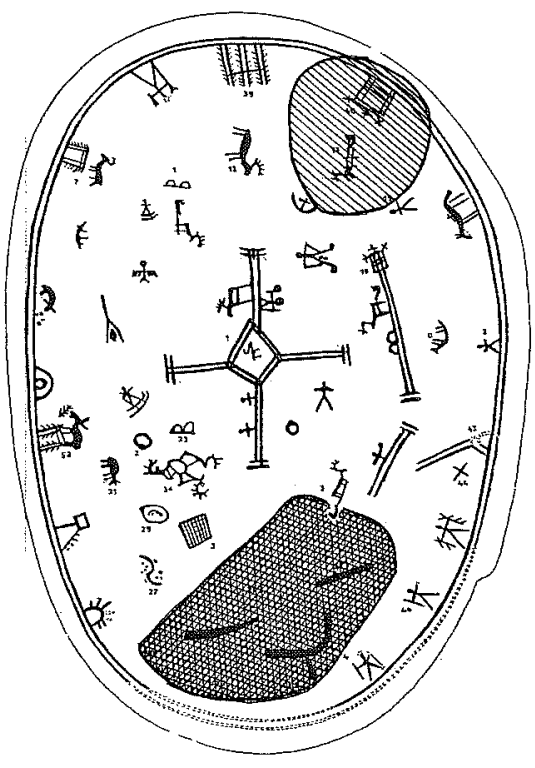

Fig 6 Drum 3
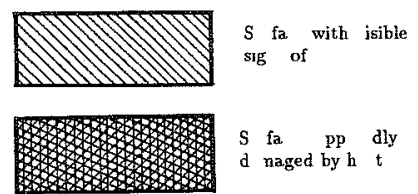

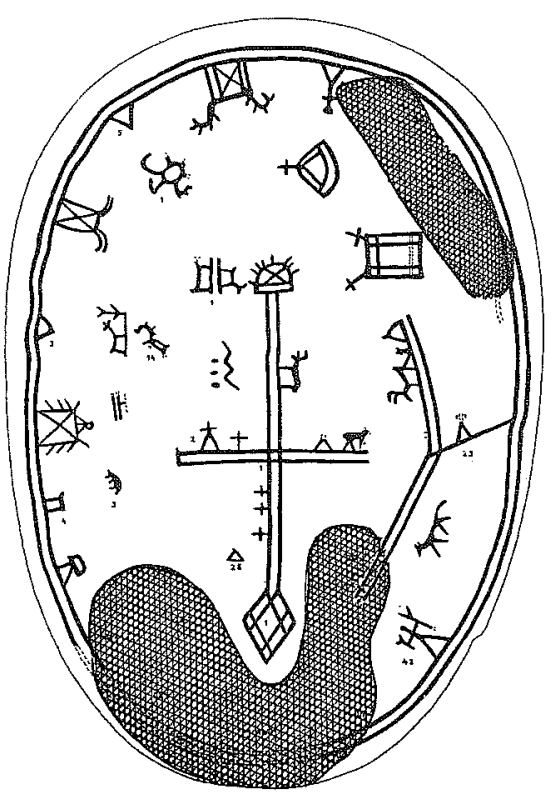

Fig 5 Drum 2

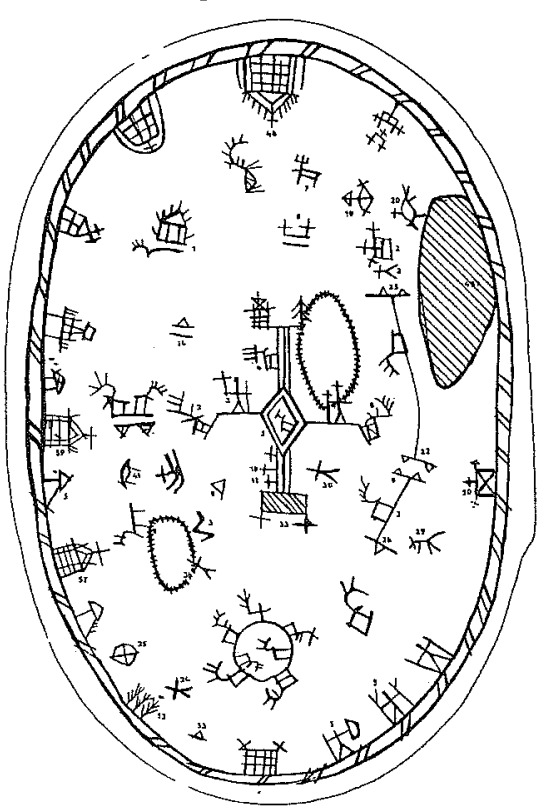

Fig 7 Drum 11

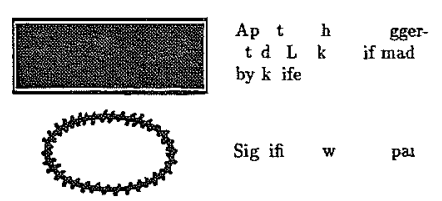



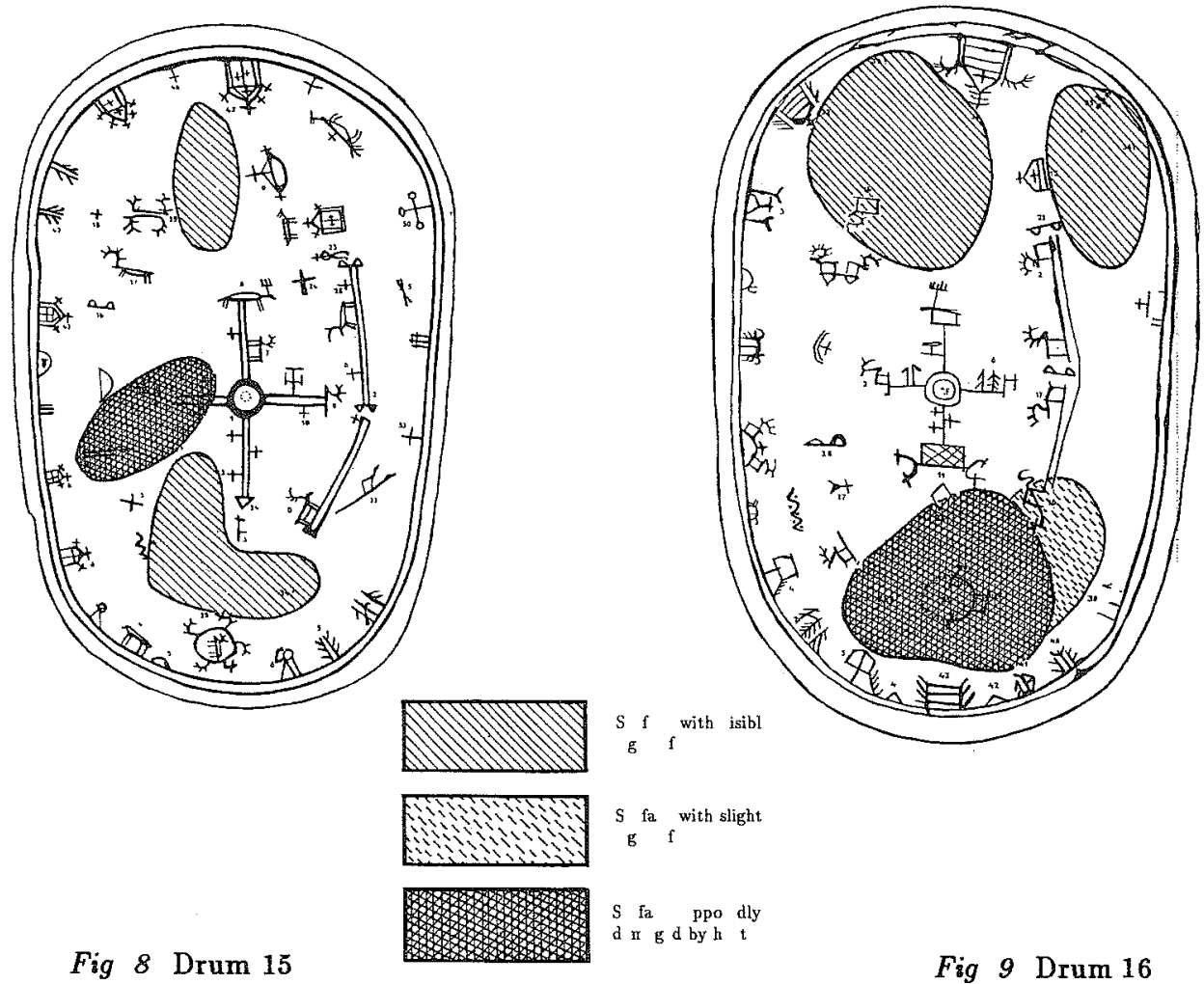

Fig 9 Drum 16

blank parts with question marks and missing figures In many cases the reason is that the drumskins are damaged by holes and rifts, or by blemishes of the surface supposedly through heat The drumskins, we are told, were often stretched by heating at the fire in the middle of the kota This need for stretching the skins is easily understood The cold and wet climate softened the drumskıns and made the sound weak and vague It was necessary to dry the skin to get a good, strong tone

There are, however, blanks in the skin surfaces which are not caused by heat or serious damage Some of those are certainly caused by use of the drums In some drums no such signs can be detected Some of the skıns are too badly damaged and some are so well kept - and perhaps too little used - so that there are no signs of usage

A comparison of the different drums shows that the signs of usage are surprisingly consistent We have mentioned that the sound of the drum depends, among other things, on the point where it is hit From laboratory experuments, it seems clear that the "best" sound, the sound with the deepest frequency and the richest variety of harmonics, 


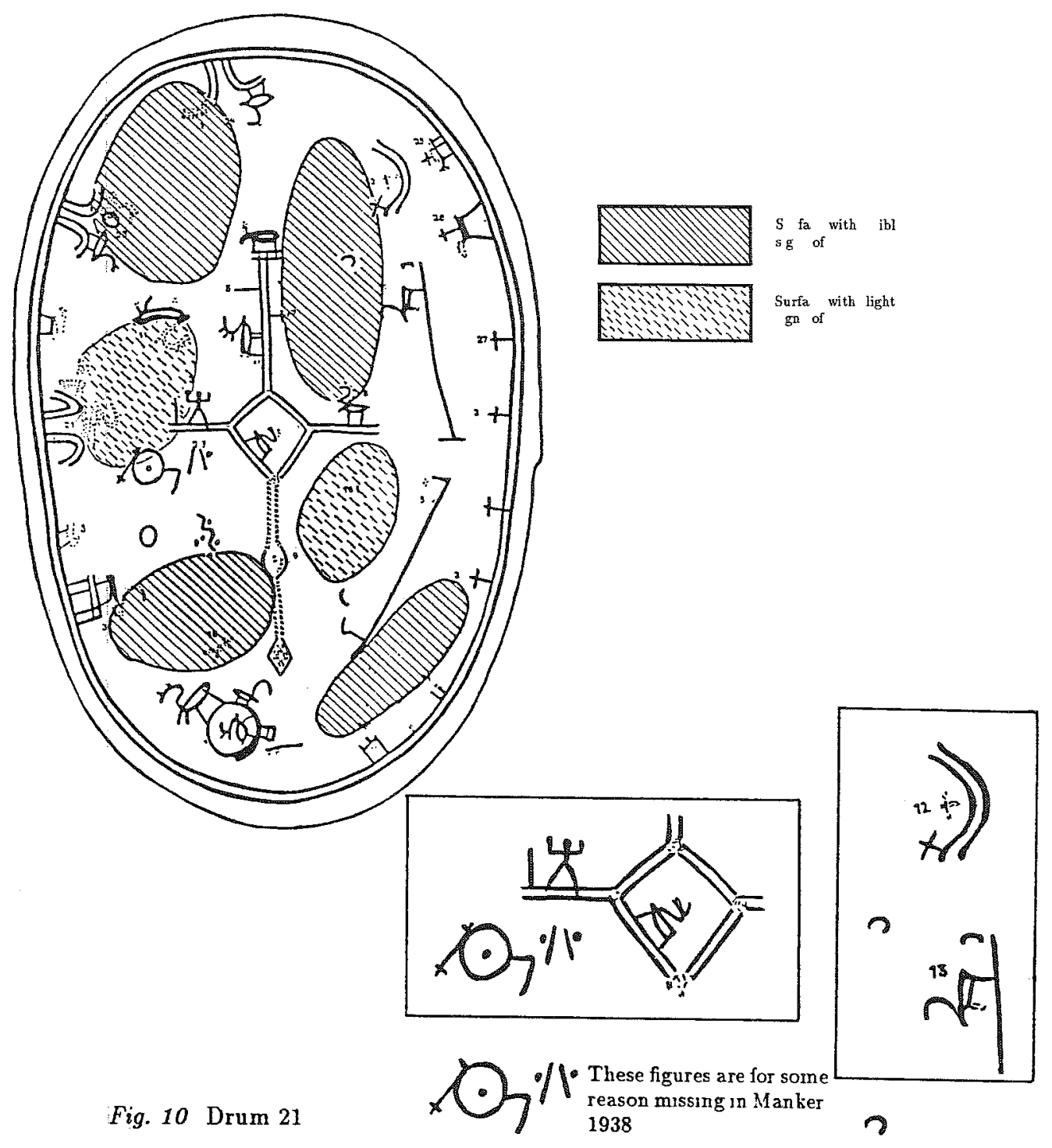

sound with the deepest frequency and the richest variety of harmonics, occurs when the drumskin is beaten on those parts of the surface where the signs are to be seen. An incidental point is that some of the drum skins which were originally imperfect were repalred by the users themselves, which may be related to the idea of the infallibility of holy things, also common among the Saamıs.

I will here present the drums I have explored (Figs 4-18) 


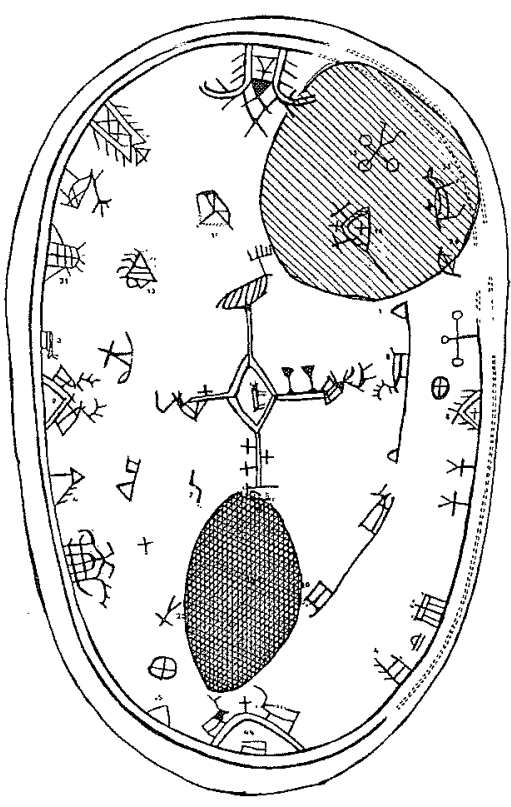

Fig 11 Drum 25

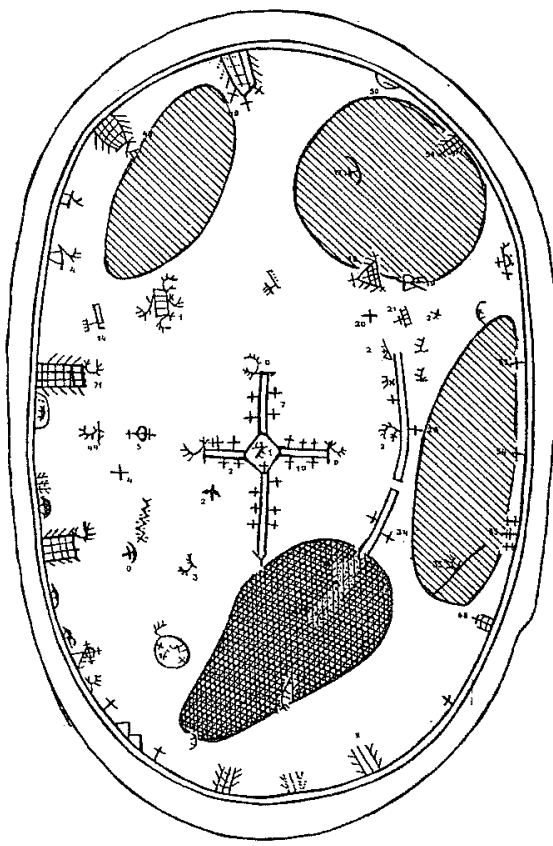

Fig 13 Drum 29

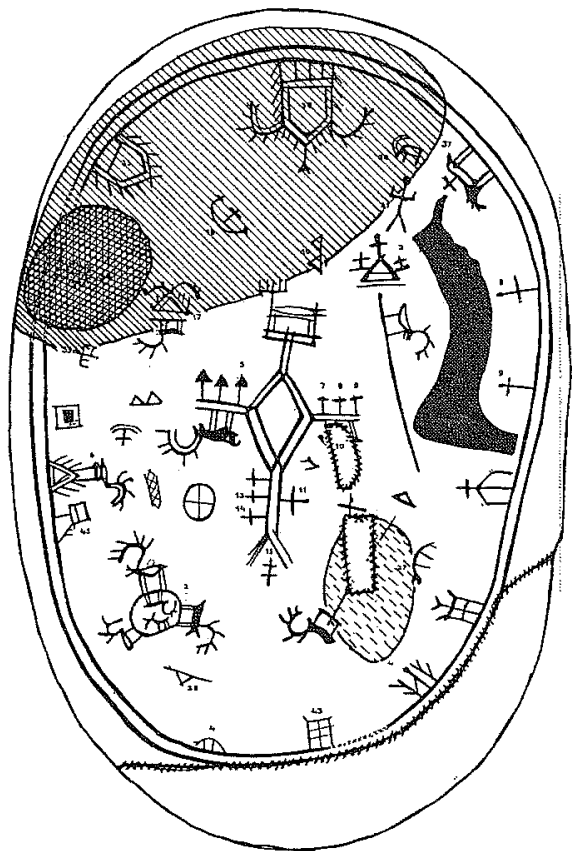

Fig 12 Drum 26

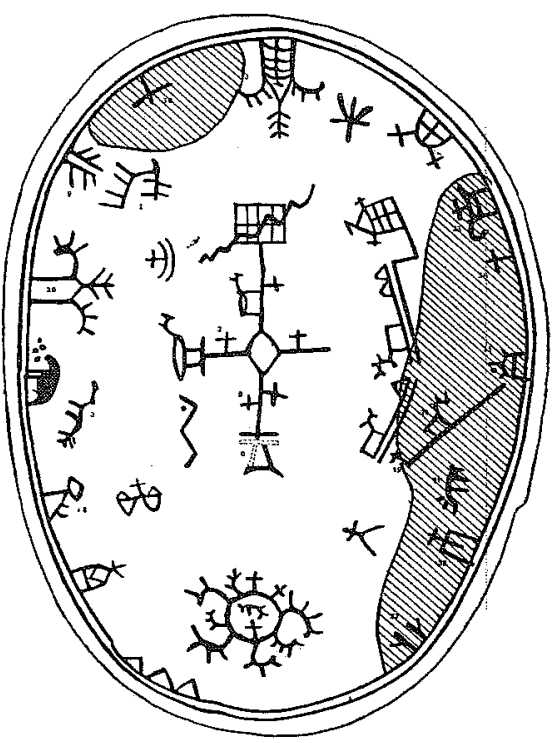

Fig 14 Drum 35

S rfa pp dly
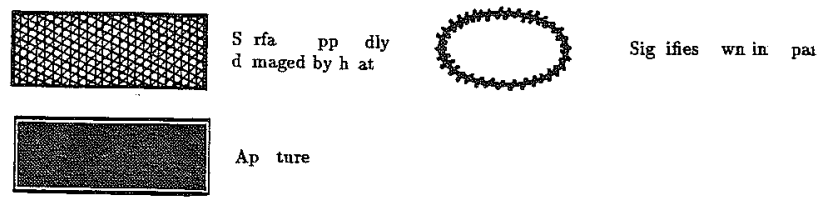


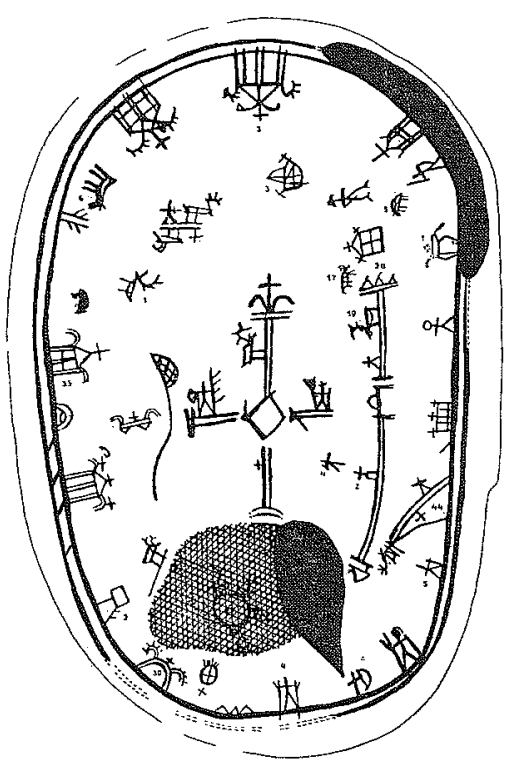

Fig 15 Drum 37

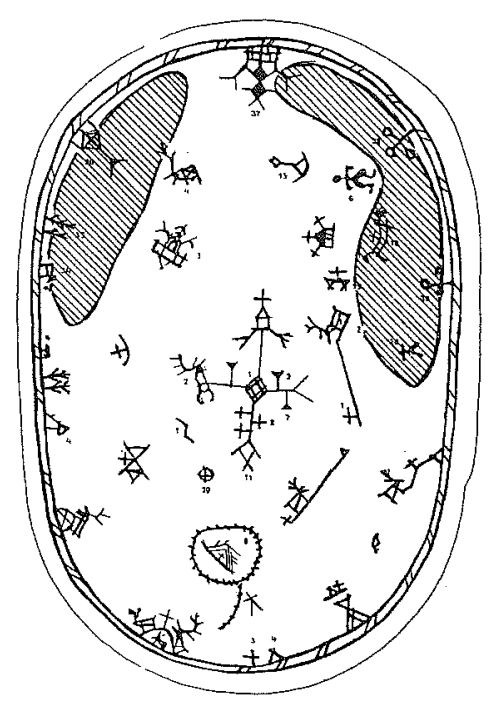

Fig 16 Drum 40.

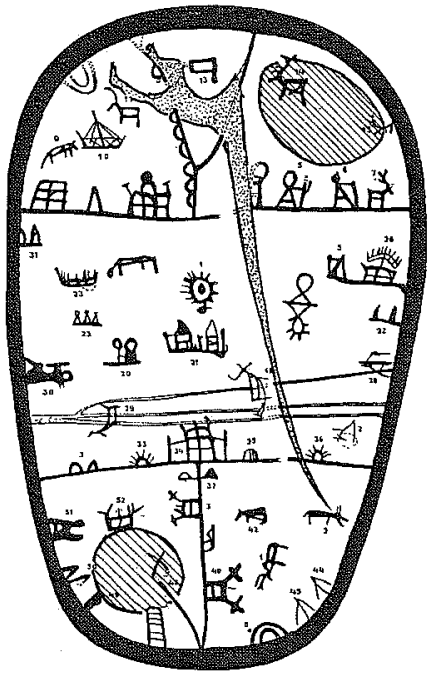

Fig 18 Drum 67
Fig 17 Drum 64

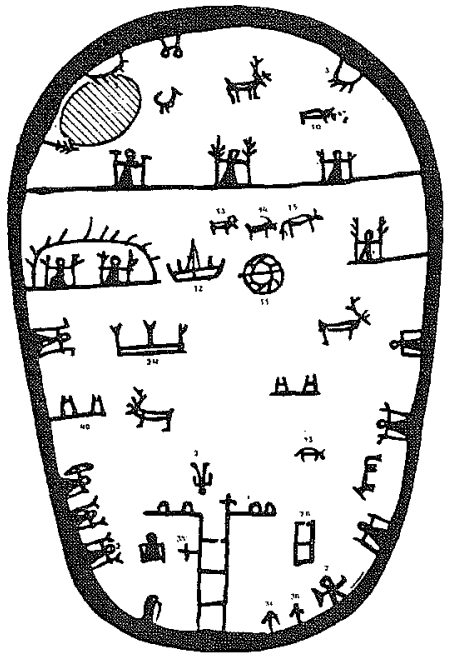

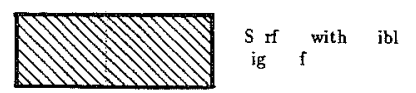

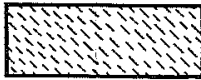

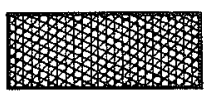

$S$ fa pp dly

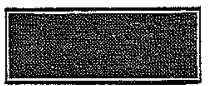

Ap $\mathbf{t}$

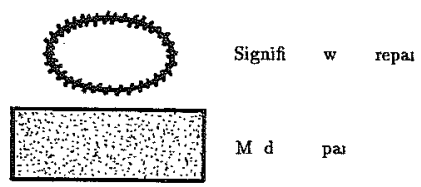




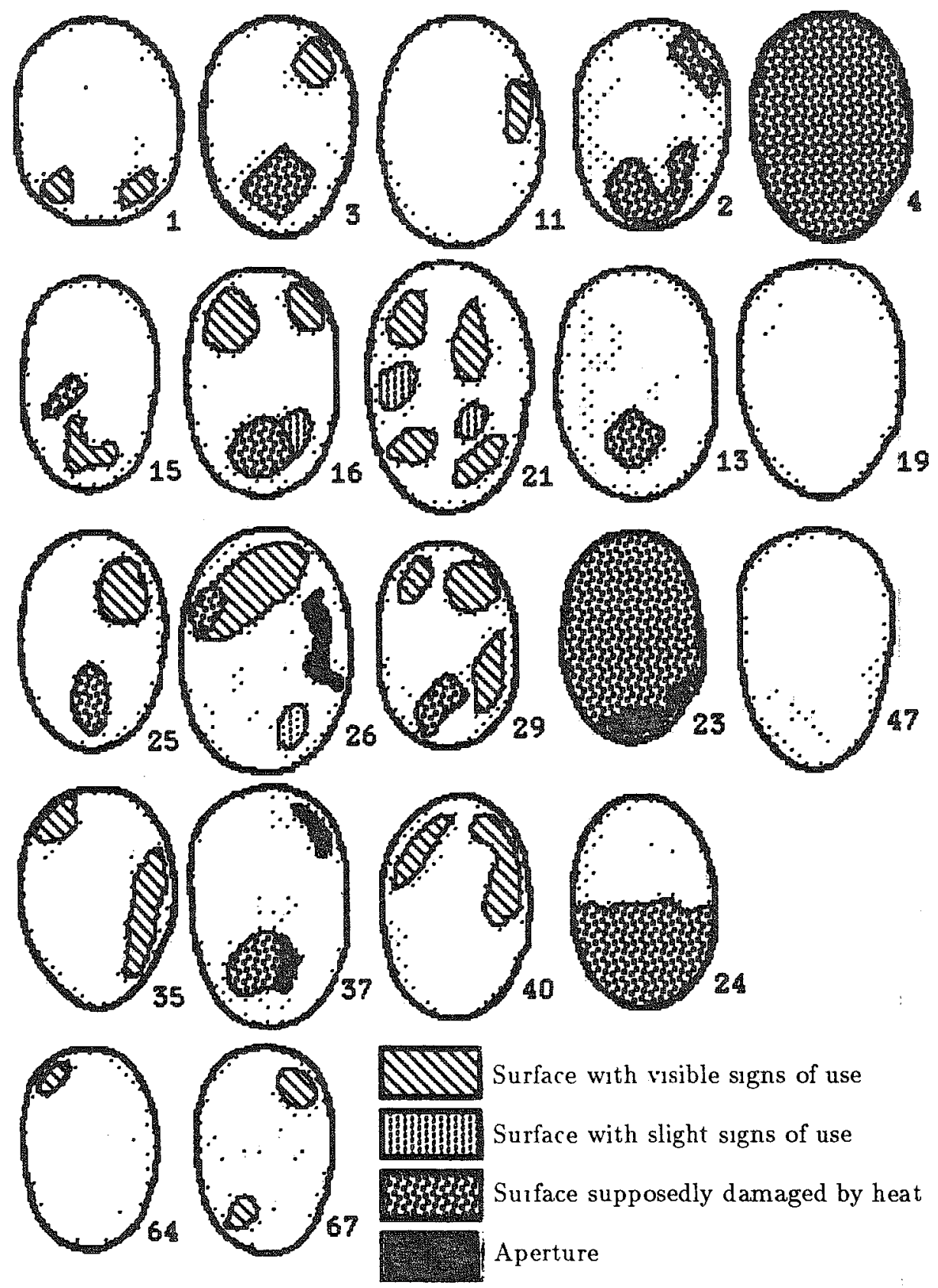

Fig 19 Comparison of drums studied 
Drums $4,19,23,24$, and 47 did not provide any information about usage Nos 4,23 , and 24 are badly damaged, presumably by heat The 21 drums compared thus give the impression seen in Fig 19

Now we have to return to the question of the arpa, or the "frog" or "pointer" Different objects were fixed to the drums hanging on strings or chains Niurenius writes: "On the drum itself, tied by sinews, hang claws and bones from all sorts of animals which they have caught The brass frog, which is their oracle, is covered all over with rings When one beats rapidly with the two headed brass mounted hammer on the middle of the drum, the rings on the frog jingle and the claws and bones make a terrible norse" (Niurenius 1905, 21) And Olao Graan tells us that "the most savage drum beater in urgent need uses a firkın lid as his drum, on which no figures are panted This was the case with a Saamı called Kobdask Păhl, who took the firkin lid in the palm of his hand, turned the plain side upwards, took a ring from his belt and, putting it on the said lid, then began to beat the lid with his knife, which he used as a hammer until he fell down and was unconscious for half an hour" (Graan 1899,60) A question here is what function was served by the ring placed on the lid It could not, apparently, be used as a pointer for divination There was nothing on the lid to point at My suggestion is, that the ring was used as a sound maker The sound made by the jumping ring supplemented the sound from the beats on the lid Thus the noaite was in possession of two vorces, one low and one high

High frequency sounds are common among shamans; such sounds include those from rattles of different kinds Michael Harner believes that sounds from rattles supplement and strenghten sounds from drums in an effective way (Harner 1983, 75). In a paper by $\mathrm{E}$ I Banyai 1t is stated, that short click sounds at high frequencies and flashes affect the EEG (Banyau 1984, $174 \mathrm{f}$ ). The experiment was carried out in order to see if it was possible to produce hypnotic conditions during physical work by stımulating alertness instead of sleep Some details in the sources indicate that this question is relevant for Saami shamanism It is said that the noaite "drives on furiously in the hut" 5

To me it seems likely that the original function of the arpa or "frog", was to supplement the drum sound with a high frequency sound in the same rythm in order to strengthen the influence on the senses in the old use of the drum as an instrument of exaltation The surviving

5 Sw “Fälas om kåtan săsom ursınng och faller omsider 1 loge” Forbus 1910, 40 
signs of usage, the marks of wear on the drum skıns, suggest that this type of practice, right into the period of cultural confrontation, was much more normal and widespread than is suggested by the written sources

We said that the designation "frog" describes the movements of the arpa on the drum skin When one lets the bunch of rings move on the drum, one is rap1dly aware that it cannot be easily directed, but has, so to say, its own will Strictly physically, the jumping is dependent on the nodes and oscillating points linked to the notes and harmonics of the vibrating skin This division of the membrane into parts cannot be seen by the naked eye If one tries to direct the "frog" by tilting the drum or by drumming at different places on the drum skin there is no means of sure success Sometimes the "frog" jumps down from the drum in spite of every attempt to keep it on the skın, perhaps several times in succession This is my experience from experiments with the drums I have built

It is quite understandable if these circumstances were interpreted as expressions of some external agent, naturally the will of the gods. From such an idea it is only a short step to the divinatory use of the instrument

\section{Bibliography}

Banyal, E I 1984 On the technique of hypnosis and ecstasy* An experimental psychophysiological approach Shamanısm in Eurasia 1 Ed by M Hoppál Göttingen

[Forbus, H] 1910 Forbus' jämförelser mellan lapparnas och de klassiska folkens gudar samt refutation af lapparnas afgudadyrkan Källskrifter till lapparnas mytologi [Ed by] E Reuterskiöld (Bidrag till vår odlings häfder 10 ) Stockholm

Fritzner, J 1877 Lappernes Hedenskab og Trolddomskunst sammenhold med andre Folks, isaer Nordmaendenes, Tro og Overtro Histortsk Tidsskrift 1, 4 Christianıa

Graan, O 1899 Relation, Eller En Fulkomblig Beskrifning om Lapparnas Vrsprung [. ] [Ed by] K. B Wiklund Bidrag till kännedom om de svenska landsmålen och svenskt folkliv 17, 2 Uppsala

Harner, M 1983 Shamanens väg Göteborg

Holmberg, U 1915 Lappalatsten uskonto Porvoo

- 1987 Lapparnas religion Uppsala

Jilek, W G 1974 Salish indian mental health and culture change: Psycho: hygenic and therapeutic aspects of the guardian sparit ceremonzal Toronto 
Manker, E 1938 Die lappısche Zaubertrommel 1 (Acta Lapponica 1 ) Stockholm

Möller, A 1976 Örat och hörseln Ljud och hur det skall låta 1976 Utg av Svenska HiFi-institutet, Red av S Jacobson et al Solna

Neher, A 1961 Auditory driving observed with scalp electrodes in normal subject Electroencephalography and Clinacal Neurophysıology 13, 3 Limerick

- 1962 A physiological explanation of unusual behavior in ceremonies involving drums Human Biology 34, 2 Detroit, MI

Niurenus, O P 1905 Lappland eller beskrivning över den nordiska trakt, som lapparne bebo [ ] Utg av K B Wiklund Bidrag till kännedom om de svenska landsmålen och svenskt folkliv 17, 4 Uppsala

Olsen, I 1910 Om Lapparnes Vildfarelser og Overtro Kildeskrifter til den Lappıske Mythologi 2 [Ed by] J Qvigstad Trondhjem

Rheen, S 1897 En kortt Relation om Lapparnes Lefwarne och Sedher [ ] [Ed by] $\mathrm{K}$ B Wiklund Bidrag till kännedom om de svenska landsmalen och svenskt folkliv 17, 1 Uppsala

Shamanısm ın Eurasıa 1-2. 1984 Ed by M Hoppál Göttıngen

Sundberg, J 1973 Musikens ljudlära Lund

Stauder, W 1949-68 Trommeln und Pauken Musik in Geschichte und Gegen wart 13 Kassel

Tornæ[us], J 1900 Berättelse om Lapmarckerna och Deras Tillstånd [Ed by] $\mathrm{K}$ B Wiklund Bidrag till kännedom om de svenska landsmålen och svenskt folkliv 17, 1 Uppsala

Wonder, J \& Donovan, P 1984 Använd båda hjärnhalvorna Borås 